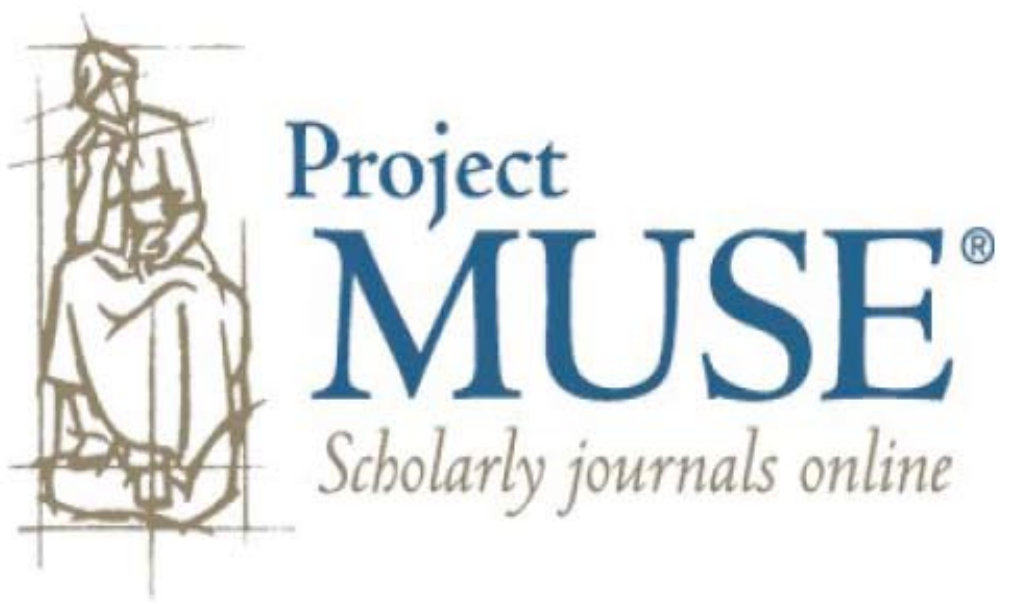


Yaron Peleg

\title{
From Black to White: Changing Images of Mizrahim in Israeli Cinema
}

\author{
ABSTRACT
}

The article examines the evolution of Mizrahi images in Israeli cinema in the past fifty years and, unlike most studies about Mizrahim in Israel, focuses on their positive portrayal. The article demonstrates the constructive ways Jewish immigrants from the Islamic world were incorporated into Israeli culture by positing three interrelated arguments. The first is that early films incorporated Mizrahim into the fledgling Israeli nation by legitimizing them as Jews. The second is that, once legitimized, Mizrahim were made part of the national Jewish family through marriage. The third is that after becoming part of the [national] family Mizrahi men were then put in positions of control and, with the decline of Ashkenazi masculinity, eventually became more genuine or authentic representatives of Israeliness.

\section{$\mathrm{T}$}

he cinematic "Birth" of Israel's ethnic divide between Ashkenazi and Sephardi or Mizrahi Jews occurs in the opening scene of the famous 1964 immigration comedy, Sallah Shabati. ${ }^{1}$ The film sets up the differences between two kinds of Jews right from the start. It opens with the landing of an airplane in the Tel-Aviv airport, from which two very different families of olim, or immigrants, emerge. The first is a worldly American couple that briskly steps down the stairs, smartly dressed in matching suits, carrying a multitude of suitcases. Following the American burghers is a very different immigrant family: Sallah Shabati (Haim Topol)— the paterfamilias and the eponymous hero of the film, his seven children, his wife, and an assortment of relatives. The family's non-Western origin is patent from their disheveled, Levantine dress; a mixture of traditional and modern clothing items, from 
their Arabic accent, and from their traditional religiosity. As they step onto the tarmac, Mr. Shabati kisses the ground and recites a blessing, echoed by a resounding "Amen" from his entire clan.

Thus begin Sallah's adventures in the Holy Land, where he is hoodwinked into accepting a "temporary" shelter in a decrepit Ma'abara, a transit camp for immigrants, where he is put to work in various mindless public works, where his vote is disingenuously solicited, and where he is patronized at every turn by callous Ashkenazim, social workers, politicians, and others. Throughout his ordeal, Sallah rarely loses his innate sweetness and good cheer. These, together with his irrepressible mischievousness and a good deal of street-smarts finally enable Sallah to beat the system, find decent housing and no doubt an honest job as well. ${ }^{2}$

Sallah Shabati became a household name in Israel and established him as the "Ur Mizrahi" whose image could later be seen in the Bourekas film genre of ethnic comedies that flourished during the I970s, in the more serious social commentaries and crime dramas from that time and finally in the Mizrahi identity films of the I990s. All of those works comment in some way or another on Sallah's iconic image and explore two of its most identifiable characteristics: the Mizrahi as an artless and good-hearted fool and the Mizrahi as a degenerate criminal. In the end Sallah triumphs because of his good heart, the naïve economy of the film necessitates it, not because he works hard or fights bravely for social justice. He is also presented as somewhat degenerate, illiterate, dirty, lazy, alcoholic, and abusive of his family. All ensuing cinematic images of Mizrahim contended with these images in one way or another.

Despite the film's unprecedented success most critiques were negative-early criticism focused on the misrepresentation of Israel's immigration and social policies. Later criticism focused on the "colonial" nature of a Mizrahi image that was both written and directed by Ephraim Kishon, and played by actor, Haim Topol, both Ashkenazis. ${ }^{3}$

This article re-examines these contentious images and discusses some of their more positive values. It offers three related propositions that deal with the perceived inferiority of Mizrahim. The first is that early Israeli films attempt to verify Mizrahim as Jews. The second is that, once their Jewish identity is validated, Mizrahim become part of the Jewish-Israeli family through marriage. The third is that, once inside the family, many films attempt to bolster the masculine credentials of Mizrahi men as part of this [national] family and at times even as leaders of it. The article examines the evolution of Mizrahi images in Israeli cinema since Sallah Shabati and 
illustrates that by the 1990s, Mizrahim, rather than being denigrated or marginalized, often epitomize the very idea of Israeliness.

Although Sallah Shabati was a commercial hit, its social and political value was questioned. Politicians and film critics were anxious about the negative and "false" image of Israel it portrayed. Few, however, doubted the veracity of the film's portrayal of Mizrahim. ${ }^{4}$ Moreover, Sallah's character as played by Topol was perceived to reflect a larger, Mizrahi collective. This was perhaps the film's most damaging imagistic aspect. Sallah's naiveté does not merely serve as a satirical narrative ploy to expose the ills of the Zionist establishment. Shohat argues that the joke is also on Mr. Shabati, who is ridiculed for being a primitive "oriental" man. On the negative side, he is a potential criminal: lazy, drunk, illiterate, and violent. ${ }^{5}$ On the positive side, this primitive Mizrahi is warmer and more genuine than his cold and disconnected Ashkenazi betters. These opposing characteristics of the Mizrahi image were a recurring theme in subsequent Israeli films.

The first significant evolution or development of the image of Mizrahim after Sallah Shabati occurred in the Bourekas film genre, the ethnic comedies that proliferated in Israel during the I970s and 1980s. Shabati's character was not only the "Ur Mizrahi", the film itself became the prototype of a chain of "sequels", which tried to capitalize on its success by copying its premise. Eventually termed "Bourekas" (after the cheap and savory pastries) these films faithfully followed the cinematic formula that was first laid out in Sallah. Most Bourekas films involved the struggles of a Mizrahi underdog against an alien, usually Ashkenazi, social, cultural, and political establishment; struggles that were often resolved through "inter"marriage: the weaker, Mizrahi character generally married into the stronger, more established Ashkenazi family. The tension between the two poles of the Mizrahi character first seen in Sallah is evident in most Bourekas films, which use comedy and sentimentalism to avoid a serious involvement with some of the more problematic issues they raise. This was perhaps the most ingenious invention of Bourekas films, which managed for the most part to maintain a delicate balance. ${ }^{6}$

The I970s and I980s were important decades in the evolution of ethnic tensions between Ashkenazim and Mizrahim in Israel and the continued popularity of Bourekas films attest both to the enduring fascination with the subject as well as to filmmakers' ability to side-step its more serious aspects. ${ }^{7}$ If the directors' balancing act may explain the popularity of the genre, which was almost the only kind of film that made money in Israel during those decades, ${ }^{8}$ the public's continued tolerance of a film genre that perpetuated negative Mizrahi stereotypes may be harder to explain. 
The dismissal or silence of the critical establishment can be explained by a disinterest in the plethora of $\mathrm{B}, \mathrm{C}$, and sometimes $\mathrm{D}$ films that were produced under the Bourekas imprimatur. ${ }^{9}$ The films' attraction especially to Mizrahi audiences, who made up at least half of the movie going public at the time, is more enigmatic. ${ }^{10}$

One possible explanation for this paradox is the visibility which films depicting Mizrahim as leading men and women gave to a community that was underrepresented in Israeli public culture and politics. Bourekas films may have provided a fictitious sense of triumph and control that was divorced from reality, but the very possibility of it which the genre suggested was satisfying for a while and served an important psychological need until the more tangible gains that came later. For members of a group who had little representation in their new country, these films offered an initial measure of recognition; if not for others, at least for Mizrahim themselves. The official State institutions may have all but ignored them, but here were these popular films that not only depicted them and their traditions, but accorded them a measure of respect as well.

The 1972 film, Salamoniko, is about the attempts of a Sephardi foreman to get ahead in life by leaving his decrepit neighborhood and moving to an affluent [Ashkenazi] part of town. Much of the film can be described as a cinematic celebration of the protagonist, Salomonico's (Reuven Bar-Yotam) ethnic-religious heritage. One of the longest and more genuine scenes in this mediocre comedy is the Sabbath ritual in Salamonico's household. Set against the hectic life of the characters who run around, scream at each other, and scramble throughout the film, the Sabbath scene stands out in its calmness, slow pace, and patient camera movements. Appearing as an anthropological study of Sephardi Jewish tradition-the Sabbath ritual and songs sung around the table, and the different dishes that the family members savor. Although the scene underscores the deterioration of the tradition it depicts (the family's adolescent Sabra children are impatient and not as respectful of it as their parents would like) it remains a central feature of the film. When at the end Salamoniko abandons his plans and returns to his old, decrepit neighborhood, simply because he loves it, 'warts and all', the warm glow of the initial Sabbath scene stands as one of the most convincing arguments for his decision. ${ }^{11}$

Much of the initial introduction of Mizrahim into Israeli culture took the form of such ethnic sentimentalism. This was a central feature of Bourekas films, which thrived on it. It was only later, during the 1990s, when Mizrahim were more genuinely incorporated into the Israeli body-culture that such expressions were labeled "Mizrahi Disneyland". ${ }^{12}$ During the 
I970s and I980s, however, they were not perceived quite so negatively, as box office receipts attest, even if the joke was ultimately on the Mizrahim. Nearly every one of the Bourekas films included "anthropological" depictions like the Sabbath ritual in Salamoniko. Although it may appear today as a somewhat naïve and perhaps even paternalistic public relations effort to endear Mizrahim by familiarizing us with their rich traditions, Bourekas films served to legitimize them, especially as Jews.

Since much of the Jewish world in Muslim countries was unknown to Ashkenazim before the Holocaust, Mizrahi Jews appeared almost "unJewish" to their Ashkenazi brethren when they arrived en-mass in Israel after 1948. ${ }^{13}$ The repeated references in Bourekas films to non-Ashkenazi Jewish traditions and folklore were also aimed at conferring Mizrahim, who were often negatively compared to Arabs, literally as Jews. ${ }^{14}$ The phrase "we're all Jews" is frequently heard in the films and reveals one of the genre's most important agendas: the construction of a Jewish, Israeli nationality that includes Mizrahim as a legitimate component.

Important recognition and legitimization occurs in the Bourekas film by Kishon, Officer Azulai (1970) about the adventures of a hapless Mizrahi policeman. The film follows many of the genre's conventions, which Kishon himself suggested in Sallah, probably inadvertently, and which he continued to explore in this film. As with other such films at the time, the comedy is primarily based on ethnic humor, physical appearance, dress, accent, antics, etc., and on the conflict between an apparently inferior or inadequate Mizrahi character and his ostensibly worthier Ashkenazi superiors. Unlike Mr. Shabati, however, who is really a bum, Azulai (Shaike Ophir) is unfit to be a policeman because he is simply too good to be an ordinary cop, not because he is lazy, uneducated, or even "primitive". In fact, in what might have been an effort by Kishon to compensate for Mr. Shabati's Mizrahi shortcomings, Azulai appears highly educated, overzealous in the execution of his duties, civilized, and chivalrous. The film's critique aims at exposing Kishon's usual target, the incompetent socialist [Ashkenazi] establishment. ${ }^{15}$

Azulai's advantage over his allegedly better, Ashkenazi superiors is gradually revealed- through his interactions with a visiting group of French policemen, with whom Azulai speaks fluent French; ${ }^{16}$ through his impressive knowledge of traditional Jewish sources, with which he manages to diffuse ultra orthodox demonstrators who clash with the police; and through his gentlemanly behavior toward women, both his wife and a young prostitute he arrests. By the end Azulai is understood as an erudite, worldly, and considerate Jewish gentleman—a mentsch, surpassing his crude and 
small-minded superiors. His incompetence may have cost him his job in the police force, but he gained membership in a much more valuable group, that of the audience or the nation.

This act of incorporation, inclusion, or compensation receives an intriguing expression in the film in the meeting of the two Mizrahi alteregos first encountered in Sallah - the fool and the criminal. In one scene in the film, Azulai takes his wife to the movies. Although off-duty, the overzealous Azulai thinks he spots a terrorist, when one of the viewers walks out of the theater in the middle of the film, leaving behind him on the floor a paper package. Azulai, who thinks he is an Arab terrorist, jumps on him only to find out, when the police arrive, that he is not a terrorist but a well-known local gangster, Amar (Yosef Shiloach). An embarrassed Azulai explains that the man who left the package behind, a few half-empty liquor bottles, looked like an Arab because of his dark complexion. "Me, an Arab?" the Arab-looking gangster with the Arab name asks with indignation. The two are then made to reconcile by Azulai's superior, who asks them to shake hands and make up. Facing each other closely the two then hug, showing their affection toward one another by speaking Arabic (!) together; both are Mizrahi Jews whose native tongue is Arabic. They conclude their reconciliation with the reassuring phrase, "we're all Jews," in Arabic.

The two sides of the eponymous hero of Sallah, the clown and the crook, are developed in Officer Azulai into two distinct and independent characters, the diligent policeman and the degenerate criminal. Both are made to meet in the film in what appears like a literal dramatization of $\mathrm{Mr}$. Shabati's character traits. The result serves two purposes. One is to formally introduce them to audiences, and if not to endear them to viewers, at least make them more palatable by acquaintance. The other, more important purpose is to legitimize both as Jews. Beyond the immediate and obvious comic value of showing two Jews reaffirm their identity by using the language of their enemies, their recognition of one another also validates their Mizrahi identity precisely because it is conducted in Arabic. The moment of recognition becomes a moment of acceptance which is immediately reaffirmed in the following scene. After they make peace, Azulai and Amar go together to a nightclub where they while the night away in a Mizrahi "orgy": they watch belly dancers, listen to Greek music, and finally dance the debka together, drunk on Ouzo, better known in Israel by its Arabic name, Arak.

The images of Mizrahim in Azulai are problematic. The dramatic elaboration of two of Mr. Shabati's most negative characteristics: the joker and the crook, perpetuates these traits as Mizrahi markers. Despite these 
negative images, Bourekas films also make many positive Mizrahi associations that revolve around the family and Jewish tradition. This was the value and power of many Bourekas films, which rehashed these images and circulated them as legally tendered Jewish-Israeli identities. This was no small matter considering some of the more mean images of non-Ashkenazi Jews that abounded in the culture shortly after the arrival of Jews from Muslim countries. In 1949, Ha'aretz journalist Arie Gelblum called Jews from North Africa a "racial immigration" and estimated that they are "unable to understand anything spiritual" and "lack roots in Judaism."17 By the I970s Sephardim or Mizrahim are closely associated in Jewish Israeli culture with traditional Judaism to the extent that they became the only meaningful expression of Jewish religiosity for the majority of a secular society alienated from more fundamental religious minorities, like national religious or ultra orthodox Jews. ${ }^{18}$

The other recurring component of the Bourekas plot, my second proposition, is that marriage between Mizrahim and Ashkenazim completed this inclusion by bestowing conjugal sanctity on it. Many Bourekas films staged cinematic marriage ceremonies that carried a clear symbolic significance. After being verified religiously as bona fide Jews, Mizrahim became aligned to the Jewish-Israeli family and made part of it through marriage whereby a member of the new, immigrant community married a member of the veteran or native community. This simplistic plot device, part of the genre's rules to untangle the [melo]drama by providing an easy way out, a happy ending, elided the entrenched inequality between the two communities. As contrived and fictitious as it was, one cannot ignore the sanguine assumption on which it was based, that the offspring produced by such unions would combine the ethnic traditions of their parents and transcend them. ${ }^{19}$

The conclusion of Salamoniko is a poignant case in point. The wedding celebration of Salamoniko's daughter Perlica (Eti Grotess)—who becomes pregnant from her Ashkenazi boyfriend Boaz Zimmerman (Menny Pe'er)— is almost a parody of this device. After the two sides agree on a mixed marriage ceremony to include both Sephardi and Ashkenazi traditions, the party then unfolds as a cacophonous and campy display of different ethnic customs. Ladino, Greek, Yiddish, Spanish, Italian, Rumanian, and Hungarian songs and dances are crammed together in a crowded montage that becomes a parody of itself: one of the guests bursts into a choreographed rendition of the aria "La Donna e Mobile" from Verdi's opera Rigoletto. The performance has nothing to do with the wedding, of course. It is merely an expression of the exuberance of the moment of unification. Significantly, 
the raucous montage ends with an enthusiastic joint performance of a familiar Israeli national ditty "for we're a jolly good nation" (as in "for he's a jolly good fellow")—really a musical rendition of the phrase "we are all Jews", with stanzas like "drink a toast and don't be shy / for the youth who fought the war / for Yemenites, Algerians and German Jews / [and drink] for the national religious youth and for disco kids too." 20

This kind of morganatic marriage is common in the Bourekas genre, whereby the drama is relieved and the socio-economic disparity is overcome by having a disadvantaged Mizrahi marry an advantaged Ashkenazi. This is the case in Sallah Shabati, where Sallah's daughter and his son marry kibbutzniks, veteran Ashkenazi natives of Israel, and is repeated in many of the genre's films, including in one of the last ones, A Little Bit of Luck (1992), directed by the king of Bourekas, Ze'ev Revah, in which the Mizrahi heroine gets together with her Ashkenazi childhood sweetheart after she endures many hardships. ${ }^{21}$

Although this marriage plot was often criticized as a shameful evasion of the much harsher reality it ignored, its cumulative effect was to further legitimize Mizrahim by including them as part of the Jewish-Israeli family. Following the legitimization of Mizrahim as Jews, the films drew them even closer by making them wives, husbands, and in-laws of Ashkenazim. Cinematic marriages in the films were nothing but a cheap, narrative device and the films themselves never served a purpose other than providing transient entertainment. It can be argued that they even supported and prolonged the disadvantaged status of Mizrahim by presenting socio-economic mobility as a matter of chance, like winning the lottery. Although this may certainly be true, Bourekas films were after all a disposable form of entertainment and once they served their purpose, they gradually disappeared. The genre peaked during the I970s as Israel's diverse ethnic communities jostled for their place in the emerging Israeli nationality. Bourekas films reflected these tensions although their underlying assumption was always "we're all Jews". Nothing expressed that more clearly than a wedding. ${ }^{22}$

Bourekas films did not only create a new Israeli family, in the process they also redefined or reshuffled gender roles, which is my third proposition. The Bourekas genre introduced a new kind of masculinity that competed with that of the existing, New Hebrew masculinity that was constructed by Ashkenazi Zionists at the beginning of the twentieth century. The reference here is to the "muscle Judaism" of early Zionism, as formulated by Max Nordau, that emerged as a reaction to common anti-Semitic images of Jews as weak, passive, and effeminate. ${ }^{23}$ The image of the New Hebrew man, slowly forged in the first decades of the twentieth century in the Jewish 
settlement in Palestine, the Yishuv, was burnished during Israel's War of Independence in 1948. The long and bloody war cost the small Yishuv I\% of its members and was credited for the most part to the heroism of these New Hebrew men of the fledgling state and its nascent army. ${ }^{24}$

The image of the New Hebrew, as articulated in such literary classics as Moshe Shamir's 1948 He Walked in the Fields, continued to reverberate in Israeli culture and inform it after independence. It eventually came to be associated with the Israeli soldiers of the IDF rather than the much smaller group of pioneering fighters that characterized the pre-independence, mostly Ashkenazi, Yishuv. Since the IDF drafted everyone, Ashkenazim and Mizrahim, the ability to excel and attain the New Hebrew or Israeli manly status it conferred was potentially open to all irrespective of ethnic background. The playing field for achieving "true" Israeli manhood was ostensibly leveled, enabling both Ashkenazi and Mizrahi men to "walk in the fields" to become New Hebrews.

The 1974 musical Kazablan is predicated on this premise, which it also examines. The protagonist of the film, Yosef Siman-Tov (Yoram Gaon)nicknamed Kaza after the city of his birth, Casablanca in Morocco-is a decorated soldier in the 1967 Six Day War. After the war, however, he cannot parlay his heroic service to the State into anything tangible, like a good job or a business. ${ }^{25}$ Unemployed, he roams his poor neighborhood with other, unemployed Mizrahi young men, whom many of the neighborhood's Ashkenazi residents regard as criminals, gangsters. Kaza is in love with his beautiful, Ashkenazi neighbor Rachel (Efrat Lavi)—an affair which is strongly objected to by her parents on account of Kaza's alleged criminality and his ethnic background. In the course of the film Kaza is wrongfully blamed for stealing money from Rachel's parents, but is eventually acquitted when the real thief is found out. Kaza then gets together with Rachel to begin a brighter future.

Kaza's negative traits are both exaggerated and domesticated through the conventions of the musical. Styled in the image of the contemporaneous African-American Black Panthers, Kaza and his gang strike an exaggerated masculine pose, with their Afro hairdos, tight outfits, muscular bodies, and confident swagger. All of these are elaborated not just by the flashy outfits and gold jewelry, but especially by the song and dance numbers that draw attention to their flamboyant display. However, it is precisely the alleged hostility and violence that attract the sheltered Rachel, who is flattered by the attention of the neighborhood's "bad boy". Their eventual love affair allows the film to offset, harness, or domesticate Kaza's frustration and rage, which threaten to disrupt the socio-economic order. 
Kazablan is clearly a modern, Israeli fairytale about a "fair princess", Rachel, and her brave and dashing "oriental prince", Kaza. If a fairytale reflects a community's hidden anxieties, desires, and values then Kaza's placement in the role of the prince is telling. Even if we view the story as a sublimation of Ashkenazi fears of Mizrahi violence and rage, the fact remains that the prince, the desired male and the paragon of manhood, is Mizrahi. The film stresses this fact by exaggerating Kaza's virility and reflecting and refracting it through the machismo of the men who surround him. Kaza is not only a war hero decorated for his bravery under fire, but also the leader of a gang of tough guys.

The story is certainly contrived, "a macho rescue fantasy", as Raz Yosef writes. ${ }^{26}$ Kaza's marriage to Rachel is a cheap narrative device; a shortcut intended to avoid a more serious contention with the cultural obstacles that prevent him from translating his military heroism into a successful post-army career. Kazablan, like many Bourekas and other films that deal with Ashkenazi-Mizrahi tensions, is explicit about the cultural marginality of Mizrahim, which Kaza epitomizes. This is also the reason why imagery, specifically the construction of a Mizrahi masculine image, becomes such an important issue in those films. The temporary inability to penetrate the real centers of Israeli power is initially overcome by the much easier manipulation of their image as compensation; an image that often takes the shape of exaggerated masculinity. ${ }^{27}$

The emergence or cultivation of an exaggerated Mizrahi masculinity should be seen in the context of two interrelated developments. One is the decline of the image of the heroic New Hebrew as exemplified by the Palmachnik after the establishment of the State and especially the transition into a more normal, national existence. The other is the concurrent emergence of a unique Mizrahi masculinity as a response to the crisis many Mizrahim experienced after immigration to Israel, especially the erosion in their patriarchal traditions. As the old, Ashkenazi, Zionist, pioneering masculinity waned between 1960 and 1980 a new Mizrahi masculinity challenged it. Both, however, exhibit surprisingly similar patterns of development in which an image that is first formed as an aesthetic response to adversity eventually shapes culture and then history in a much more tangible sense.

The New Hebrew refers to the aesthetic formulation of a "muscular Judaism" by ideologues, writers and artists like Max Nordau, Theodor Herzl, and Moses Lilienblum as an aesthetic response to the negative portrayal of Jews in Europe. ${ }^{28}$ As the Yishuv developed, these aesthetic sensibilities influenced the new Hebrew society and culture in more tangible 
ways. ${ }^{29}$ By 1948, the neo-biblical farmer-fighters of early twentieth century Hebrew writer Moshe Smilansky, for instance, or Lilienblum's illustrations of modern Maccabees, were almost literally embodied in the Palmachnik, the paramilitary soldier-farmer who was shaped in their image. What began as art gradually influenced life.

The success of the Palmachnik in securing independence also led to his retreat from the forefront of the Zionist revolution once his job was done. As Israeli society became less mobilized and the zeal directed at founding the State was channeled into the more mundane business of running the country, the epic Palmachnik gave way to a more professional soldier. ${ }^{30}$ The romance of the nation's birth became less romantic. The heroes of the past gradually became tamed burghers, a middle class of skilled laborers, shopkeepers, businessmen, and politicians. The image of the soldier-farmer continued to reverberate in the culture but it was increasingly relegated to the past, eventually becoming nostalgic and finally mythological. ${ }^{31}$

Mizrahi masculinity filled the space that was vacated by the retired New Hebrew man. Here too, the emergence of an overt, non-Ashkenazi masculinity as depicted in Kazablan originated as a reaction to negative stereotypes of Mizrahim, very much like the dynamic that gave rise to the New Hebrew image at the end of the nineteenth century. The hurried immigration to Israel of many Mizrahim during the I950s led to a breakdown in their traditional ways of life, which were drastically disrupted during and after their move. In addition to the usual vagaries of migration, the move to Israel exacted an especially high toll on Mizrahi families. Unlike many of the Ashkenazim who came prior to independence as young, single, and ideological pioneers, men and women who rebelled against their diasporic families, most Mizrahim moved to Israel as intact family units. The opening of Sallah Shabati illustrates this well.

While this probably eased the move somewhat and provided a degree of comfort and sustenance during the crisis of uprooting, it raised other difficulties. Chief among them was the change in the role of the Mizrahi paterfamilias, whose position as head of the family was seriously undermined by immigration. Unlike their younger children, who adapted quicker and easier to the new culture they encountered in Israel, Mizrahi fathers were slower to do so. The loss of property, professional accomplishments, security that came with cultural familiarity, as well as middle-age, made the transition more difficult for the generation of Mizrahi parents. It did not help either that the traditional Arab cultures they came from were more patriarchal in comparison to the young and irreverent Israel. The idea of honor, which was inextricably connected in Arab cultures to the traditional 
role of men as fathers, brothers, and husbands, was eroded in the dynamic, socialist, and more sexually permissive Israel. These forces wreaked havoc on the actual function as well as the self-image of Mizrahi men, especially fathers and husbands. ${ }^{32}$

In some ways, images of hyper-masculine Mizrahi men in Israeli culture, especially films, compensated for the emasculating immigration and absorption experience. The loss of control over individual, family, and community life was channeled instead into the construction of an alternative fantasy of control, that of the macho male. Kaza's gang members offset their socioeconomic marginality with an accomplishment that is shorter lived perhaps, but quicker and easier to attain, menacing their neighborhood. Brandishing their muscular bodies they gain the respect that otherwise eludes them, not just from their neighbors but from the establishment too, the police. That they are feared rather than respected does not matter. The hunger for respect is so pressing that it must suffice for the short run. The leading song from the musical is literally called honor (kol hakavod) and touts Kaza' 33

The formation of the Mizrahi macho man developed not just because of their disproportional concentration in the lower rungs of society, the "criminal" strata, but also against the decline or metamorphosis of Ashkenazi masculinity, which it eventually replaced. One of the most visible places where this shift occurred was in the realm of sex. In many films from the I970s and 1980 os Mizrahi men clearly emerge as sexual objects. ${ }^{33}$ Sex, writes Raz Yosef, "offers for Mizrahi males a space for emotional and bodily expression, self-encouragement and self-affirmation that contests the oppressive conditions of Israeli social reality." 34 For Yosef, however, this cultural construction indicates "the Orientalist beliefs of Zionist racist ideology" (!), which sees Mizrahim as people who "think" with their bodies rather than with their minds. However, if we consider the marriage ceremonies that conclude many Bourekas films for instance, and if we look especially at the gender division of these "mixed" marriages, a different picture emerges. In many of these films the desired male is Mizrahi while the desired female is Ashkenazi.

Kazablan is an obvious example, and so is Katz and Carasso, although in other ways. Both Kaza in Kazablan and Ossi Carasso (Yehuda Barkan) in Katz and Carasso are attractive partly because they are bad-boys, daring, independent men who defy social conventions. Kaza's stylized defiance is expressed through his criminal association. Ossi's "criminality" is sublimated and bourgeoisified by making him a playboy, a rich kid who runs wild, drives fast, expensive sports cars, lives lavishly, parties, and womanizes. That is why he is so attractive to the Ashkenazi Naomi Katz (Efrat Lavi) the 
quiet, bookish, and diffident daughter of his father's business rival. The film makes the gender associations between Ashkenazim and Mizrahim not just doubly but squarely obvious by giving the Mizrahi Carasso two sons and the Ashkenazi Katz two daughters. ${ }^{35}$

When the reverse occurs, as in Salamoniko, whose daughter Perlica marries the Ashkenazi Boaz Zimmerman, the attraction does not seem to be personal as much as connected to the boy's economic status. When Salamoniko charges into the Zimmerman household to demand that Boaz marry his daughter after getting her pregnant, the scene emphasizes the affluence of the parents much more than any personal attributes of their son or the connection between the lovers. ${ }^{36}$ Entering the scene late and relegated to the margins of the frame, Boaz (Menny Pe'er) looks almost pathetic in his unfashionably baggy shorts and scrawny white legs; an effeminate and bookish mama's boy, that is: a typical Ashkenazi.

The image of Boaz Zimmerman as goody-two-shoes, a well-to-do, overly educated, and obedient Ashkenazi sap emerged simultaneously with the development of Mizrahi machismo and complimented it. This is patent in movies like Lemon Popsicle (1978)—a huge hit that inspired seven sequels. Taking place in 1950 S Tel-Aviv, the film is a nostalgic coming-of-age story that revolves around three adolescent boys. The moral hero of the filmBentzi (Yiftach Katzur) - is in love with the high school's beauty, Nili (Anat Atzmon). Nili, however, prefers the handsomer and manlier Momo (Jonathan Segal) who dates her briefly but leaves her after he finds out that he got her pregnant. Bentzi, who truly cares for Nili, helps her go through an abortion, hoping to prove his real worth and the depth of his love for her. But after Nili recovers she leaves Bentzi and goes back to the dashing Momo again. ${ }^{37}$

Directed by Boaz Davidson, who worked on many Bourekas films during his prolific career, Lemon Popsicle is an Ashkenazi Bourekas, that is, a "gefiltefish" comedy that focuses almost exclusively on Ashkenazi society. ${ }^{38}$ Made a year after the historic 1977 election, in which Mizrahi voters helped end 29 years of Ashkenazi political control by supporting the Likud, the film combines nostalgia for youth with nostalgia for an Israel unencumbered by ethnic divisions. ${ }^{39}$ The nostalgia, however, is selective. The film does not hanker, for instance, for one of the central features of early I950s Israeli society: the heroic image of the Palmachnik. In fact, Bentzi, the film's hero, offers a strikingly different image altogether. He is slight, quiet, introverted, and polite; almost a sissy. This may indeed be the reason why he does not get the girl at the end. At the same time, he remains the undisputed hero of the film, a man whose inner worth and emotional 
maturity is preferred by viewers to Momo's greasy good looks and smarmy sex appeal. The image of the forthright New Hebrew that emphasized body over mind, action over words, and practical experience over scholarly erudition changes in Lemon Popsicles. Bentzi is closer to the pre-Zionist Jewish weakling than he is to a brave Palmachnik or his IDF manifestation, the commando fighter. ${ }^{40}$

The transformation that the film depicts is an almost "transvaluation of values", symbolic and important not just because it was validated by a number of successful sequels but also because it appeared at a specific juncture in Israeli history. The popular support that brought Likud to power signaled the first expression of real not simulated Mizrahi power. Until then, Mizrahim were primarily engaged in cultural identity politics, first proving their legitimacy as Jews, then making sure they marry into Ashkenazi families, and finally asserting themselves as men. The vote for Likud realized the power and potential that was always inherent in these images. It lifted them from the screen and transformed them from a virtual force to a political one. ${ }^{41}$ Simultaneously the entrenched Ashkenazi regime and its supporters experienced a defeat that, symbolically, subjected them for the first time to the domination of Mizrahi power. Lemon Popsicle signals the reinterpretation of Ashkenazi masculinity as a reaction to these culturalpolitical changes. The slender, sensitive Bentzi is a new kind of Israeli hero, one that has more in common with his diasporic Jewish grandfathers than with his brave, New Hebrew father.

In the decades that followed, the image of the Ashkenazi as a "Bentzi", a laflaf was further developed. Ashkenazi-laflaf became a common phrase to which leftist political leanings were usually added together with love of Arabs, Israel's enemies. ${ }^{42}$ Having proved their masculinity during the War of Independence and having secured their financial future after I948, Ashkenazi men no longer had to prove themselves and could relax. At the same time, Mizrahi men developed the image of the ars in opposition to the laflaf. A Kaza-like Mizrahi man, the ars was confident, brash, and sexually attractive, someone who expended most of his energies, either aggressively toward men or sexually toward women, on ensuring others respect him. ${ }^{43}$ The ars' preoccupation with respect, and his political nationalism fit well into some of the developments shown above, especially the historical alliance with Likud as an expression of political rebellion. Toward the end of the 1980s, two of the most extreme or visible models of Jewish masculinity in Israel were these two opposing types, the laflaf and the ars. ${ }^{44}$

The evolution of this division or development is clearly evident from some of the films quoted above. The partial fusion of these two images in 
the I990s is evident in a seminal film-Shuroo (I99I) — directed by Savi Gabison, written by Jonathan Arout and Jonathan Raviv, in which a quasiMizrahi guru becomes the spiritual guide of a group of Tel-Aviv Ashkenazi and Mizrahi socialites. Asher Yeshurun (Moshe Ivgy) is a charismatic loafer who lives in Tel-Aviv with his wife Shimrit (Keren Mor) a university student and a poet. His latest project is a self-help book on how to lead a happy life by teaching readers to be idiots. Surprisingly, even for him, Asher's "philosophy" attracts a small group of acolytes who hope to escape their numbing bourgeois life to find love, hope, meaning, and redemption through him. Shuroo is seminal because it is a film about a society in search of a meaning at a pivotal time in Israel's history. Secondly, it is a film that clearly includes Mizrahim but takes no note of their difference. Thirdly, to the extent that it does distinguish between Mizrahim and Ashkenazim, the film positions the former in the role of spiritual guides or gurus.

The film's immediate success was due in large part to the timing of its release. The fantastic, eerie atmosphere that took hold of Israel when SCUD missiles fell at the height of the Gulf War in 1991 fit the bizarre comedic sensibilities of the film. It also came at a significant juncture in the country's history, at the beginning of a so-called post-Zionist era when many of the country's former truths were being reexamined. Shuroo is premised on a search, a spiritual search for meaning at a time made all the more confusing by the relative comfort of its characters' lives. The Oslo Accord of 1993 and the concurrent mass immigration of Jews from Russia boosted the country politically and economically despite the first Intifada in 1987 . Since comfort was until that time a strange and unfamiliar condition for most Israelis, the film attempts to question or shake it with its acerbic humor and the seemingly disjointed episodes that make it up.

One of the more symbolic of these episodes involves members of a singing group, modeled on the real kibbutz troupe Gevatron. Dressed in white kibbutz shirts, the group of singers wanders through the streets of Tel-Aviv after a performance, looking for the bus that will take them back home; "a light-blue bus with sheaves of wheat painted on it", as they describe it. Utterly lost, these stylized kibbutzniks look completely out of place in the gritty, late-night streets of Tel-Aviv. The parody of good-old, labor-Zionist Israel which they convey, an old-fashioned and extinct kind of Zionism, becomes poignant during their performance of the film's title song, Meir Ariel's "The Snake's Slough". Sitting on hay bales that neatly adorn the stage, they harmonize the sad and confused lyrics of Ariel's urban existential poem as if it were one of the naïve songs from their usual repertoire, full of love for the land and its nature. Their very appearance, stylized, 
exaggerated, out of context, is ludicrous, of course, like their mellifluous rendition of the song, whose overly sweet harmony sounds absurd, out of place and especially out of time. These are not genuine country bumpkins who bumbled into town by mistake, but a carefully rehearsed simulation of the "kibbutz experience" on tour. It is a parody of the old-fashioned values of labor-Zionism on which the State was founded and which by then had become irrelevant and invalid; calcified remains of a glorious past.

Although Shuroo does not take direct note of its characters' ethnicity, the trained Israeli eye and ear can nevertheless pick up on it. In addition to obvious Mizrahi accents and appearances, like those of the taxi driver Zhaki (Albert Iluz) or the vegetable grocer Mordecai (Yigal Adika), there are other hints. Asher's ethnic background is never discussed, but the actor's Moroccan background, his non-native Israeli accent with its rolling R, his probable Mizrahi name, as well as the way his aging father looks (he wears pajamas, a French beret, and stubbly facial hair) identify him almost certainly as Mizrahi. None of these matter. Unlike the obvious signs of difference in Sallah Shabati which drive the film's drama, the distinctions between Mizrahim and Ashkenazim in Shuroo are blurred and unimportant from a dramatic standpoint.

Because Asher Yeshurun is Mizrahi, his status as guru is significant. His disciples are a motley bunch that include academics, business people, wealthy socialites, and miscellaneous others, Ashkenazim and Mizrahim. The group's diverse makeup illustrates the film's tendency to obscure or in fact flatten ethnic distinctions in order to talk about a general "Israeli condition". Aside from the group's significance as a symbol of the Israeli collective, they all seem to suffer from acute ennui. Some of them, like Shimrit, write ludicrous poetry while her mentor, Professor Konar, cultivates sadomasochistic tendencies. Others like the greengrocer Mordecai and the pub owner Eli explore their sexuality together, while others, like the television producer, Tal, try to express themselves by "flying" out of the window and end up crashing on the sidewalk beneath. All of these function more as eccentricities rather than the real problems of a privileged bourgeoisie who have nothing more serious to worry about.

Asher's new-fangled philosophy fills the vacuum in these peoples' lives. Nevertheless, his cultivation of idiocy as a way to happiness goes beyond the obvious satire of the self-help industry with its faddish dogmas and gurus to match. In a way, the inanity and nonsense Asher promotes are a negative mirror image of the high idealism of previous generations. To counter, resist, and protest the fervent ideals of the forefathers; ideals that have not only become irrelevant but also harmful, Asher, the grandson, chooses no 
ideology at all, an attempt to vacate the mind from any thought whatever. "Didn't you notice how idiots always smile?" he asks his interviewer on TV. "It's because they're happy." His goal is to make people happy by encouraging them to act like idiots. "Start by doing one inane thing a day," he says to viewers, "you'll immediately feel better."

Although the film never says it quite so directly, Asher is an exorcist of sorts. He tries to cleanse people of an excess of lofty deeds or ideals, which at the historical moment he occupies in Israeli history have become far more damaging than inspiring or constructive. He voices an inchoate protest against an Israeli nationalism gone awry; a national ideology that has changed from redemptive to oppressive; from redeeming Jews to oppressing Arabs or Palestinians. The ennui that inflicts the sated burghers in Shuroo is shockingly irresponsible in light of the problems that Israel faced at the time and especially in light of the plight of the Palestinians, their very close neighbors. Asher's pursuit of idiocy, his encouragement to be "about nothing" as the contemporaneous American TV star, Seinfeld, put it, is a biting satire. His failure at the end to help his followers reach a state of blissful emptiness is actually his only constructive success. ${ }^{45}$

Ashers' new idealism is to have no idealism at all. To that end his relationship with his mute and crippled father is telling. Asher's wheelchair-bound father who does not talk highlights the shift between the first generation of Mizrahi immigrants and their Israeli children. The father's immobility and silence stand for his generation's inability or reluctance to participate in Israeli politics and culture. The father is literally crippled and dumb; a handicap for which the son compensates with his dynamism and his impressive communication skills. If the Mizrahi father has been silenced and disenfranchised, Asher, his Mizrahi son, is now completely in control, the Lux et Veritas, the guiding light, the Shuroo, that is Asher-guru of a new Israeli generation.

Asher's ambiguous Mizrahi identity is also a function of his mixed masculine identity, which is part Mizrahi, part Ashkenazi. Although he is slightly dark, has a slight accent, and an obviously Mizrahi father, Asher is an integral part of Tel-Aviv bohemia. He sports fashionable sunglasses, a fashionable hairdo, wears smart clothes, has a poet for a wife, and consorts with wealthy, sophisticated friends. These trappings were not usually associated with Mizrahim in films. In Salamoniko, for instance, these are precisely the marks that separate and alienate the protagonist's Sephardi family from their wealthier, more educated neighbors. Asher is also the author of a book that helps people get in touch with their emotions. From a macho perspective, nothing can be more laflaf than this expression of 
mind over body. "Real" men do not do such things. However, Asher is not a laflaf at all. He is confident and self-possessed; he is clearly a leader who commands honor from people and he is very attractive to women. He ably combines both masculinities, the Mizrahi and the Ashkenazi. That is part of the reason why his ethnic background is ambiguous. It is also part of the film's message, which is predicated on a fruitful mixture of opposites: men and women, Mizrahi and Ashkenazi.

Shuroo clearly brings an end to decades of cinematic separation between Mizrahim and Ashkenazim and presents a much more integrated society. In some respects, it can even be argued that the film presents Mizrahim in positions of control or at least authority. The film charges Asher with the responsibility to question the past, fill the void created by the dawn of a new era and perhaps even articulate a new vision for the future. By integrating the Mizrahi Asher completely into Israeli society Shuroo ends the identity politics of the Bourekas film genre, the attempts to legitimize Mizrahim as Jews and incorporate them into the Israeli body-culture. His advancement to the center or even the forefront of Israeli society, the solid footing on which he stands in Shuroo, opens up Israeli cinema to a new kind of Mizrahi identity exploration. This is no longer the apologia of the Bourekas with its socio-cultural, positivist agenda but a more genuine attempt to come to grips with Mizrahism.50

\section{Notes}

I. Ephraim Kishon, director. I use Mizrahi in this article to designate nonAshkenazi Jews who originated in Muslim countries and were traditionally defined in Israel by their non-establishment status.

2. The Yiddish-speaking American couple who traveled with Sallah is never seen again. Presumably their wealth and connections eased their absorption considerably.

3. Ella Shohat sees the film as a classic example of Foucauldian power relations, whereby Mizrahim are falsely represented and denigrated as a means of control. Ella Shohat, "Sallah Shabati: From Nowhere to Nothing," Proza, Ioo (JanuaryMarch, I988) I69-I7I [Hebrew]. See the article at http://www.amalnet.kı2.il/sites/ commun/library/cinema/comio378.htm.

4. Shohat writes that critic Yosef Sarik saw the film's main value in its documentary quality, Ibid, I69.

5. I began with Shohat's critique not only because it is well-argued and seminal but also because it provides a striking contrast to the eventual progression of 
Mizrahi images in Israeli cinema. Her critique is based on postcolonial principals that are often ill suited to the Israeli case. See my study, Orientalism and the Hebrew Imagination (Ithaca, NY, 2005).

6. The enduring popularity of Bourekas films was verified in a poll conducted in 2004 by Ynet, the web edition of the daily Yediot Ahronot. Four Bourekas films were included among the first Io movies out of the 56 Israeli films ranked by viewers. The genre's popularity is its authenticity: "Bourekas films have remained the most uniquely Israeli cinematic genre [ever made in Israel]." Shmulik Duvdevani, "The People Voted Sergio," http://www.ynet.co.il/Ext/Comp/ArticleLayout/ CdaArticlePrintPreview/I,2506,L-2907674,00.html, 26.4.2004.

7. I refer here primarily to the gradual rise in Mizrahi awareness that was expressed politically through the ousting of the entrenched socialist and mostly Ashkenazi governments led by the Labor party and the support of the more nationalistic Likud party, which replaced it in 1977. Cultural aspects of these changes included the increasing legitimacy of Mizrahi artistic expression in the national arena. In 1982 Zohar Argov topped the national Mizrahi song contest, broadcast on national TV, with his electrifying performance of the song "The Flower in My Garden," paving the way for the unprecedented flowering of Mizrahi music in the I980s and I990s.

8. Nurit Gertz, Motion Fiction, Israeli Fiction in Film (Tel-Aviv, 1993) [Hebrew].

9. Initially, most critics rejected Bourekas films as frivolous, escapist, antiZionist, for refusing to seriously deal with the country's pressing problems, Ibid., 32-33.

IO. There are no statistics on the specific ethnic background of movie-goers in Israel. However, the high numbers of tickets sold and the relative low cost of movie tickets would support my hypothesis irrespective of income levels simply based on the percentage of Mizrahim in Israel, who, before the Russian immigration in the I990s, made up close to $60 \%$ of Israel's Jewish population. Gertz lists several indices about the nature of Bourekas films' viewers that identifies them indirectly as Mizrahi, noting that the number of movie tickets purchased in Israel during the I960s matches that of a country with a population of 8 million and not 3 million Israelis numbered then. Ibid., 33-34.

II. One of the earliest versions of this kind of ethnic detail is Menachem Golan's I966 film, Fortuna, about the life of Moroccan immigrants in Israel's south.

I2. Rona Ra’anan-Shafrir, interview with Ronit Matalon, "No One Has to Read This," Kolbo, March 20, 1992.

13. Arie Gelblum's notorious Ha'aretz article of April 22, I949 used racist terminology to describe Jewish immigrants from Arab countries. The theme frequently appeared in Hebrew literature. One of the Ashkenazi characters in Yehoshua Kenaz's novel Infiltration (Tel-Aviv, 1986) 36I, (about a group of army recruits in the 1950s) writes the following to his Iraqi-born fellow soldier: "And you, are you Jews? You're Arabs, that's all you are. There aren't any such Jews ... you're just Arabs who're afraid of eating on Yom Kippur. That's all.” [Hebrew]. 
I4. The importance of the Mizrahi ethnographic components as part of Bourekas films becomes especially apparent when compared to their absence in the quasi Bourekas films of Iraqi-born director George Ovadia. As cinematic prototypes of TV soap operas, Ovadia wrote, directed, and produced several sentimental melodramas during the I970s and I980s that transcend the narrow ethnic confines of most Bourekas films (Nurit, 1972; Sarit, 1974). Precisely because they lack a lot of ethnic references, Ovadia's films cannot be considered pure "Bourekas". His films are Hebrew versions of the maudlin melodramas that were produced at the time all over the Arab world.

15. Kishon was Ashkenazi, but he did not support Ben-Gurion's labor party.

I6. Although Azulai's background is unspecified, his last name and knowledge of French identify him as Moroccan.

I7. Gelblum wrote: "This is a racial immigration the likes of which we had not seen before in Israel . . . We have before us an incredibly primitive national group ... Unlike the Yemenites, these Moroccans also lack Jewish roots."

I8. Eran Kaplan, "Israeli Jewry," in Nicholas de Lange and Miri Freud-Kandel (eds), Modern Judaism: An Oxford Guide (Oxford, 2005); Baruch Kimmerling, "Between Hegemony and Dormant Kulturkampf in Israel," in Dan Urian and Efraim Karsh (eds), In Search of Identity: Jewish Aspects in Israeli Culture (London, 1999) 62-64.

19. Some scholars refute this premise and present it in a much more sinister light. Raz Yosef sees this as a cooption of Mizrahim by the ruling Ashkenazi classes. He mentions a 197I Israeli joke that made light of this issue by predicting that Israel's ethnic tensions will be solved in bed. Yosef regards the joke and the attitude it expresses as a glib attempt to cover up deep-seated Ashkenazi racial fears. See "The Invention of Mizrahi Masculinity," in Beyond Flesh (New Brunswick, NJ, 2004) 99n33. The proliferation of Bourekas films and their popularity undermine his premise that the most that these films can be "accused" of is the promotion of the mantra "we are all Jews," which tends to gloss over differences rather than face them directly. The obsession with cultural and political unification has been an inherent part of Israel's history. Mizrahim were not the only group to be co-opted. The attempt to subjugate all immigrant groups to the Zionist pioneering ethos during the I950s and I960s has been conclusively documented by Tom Segev in 1949, The First Israelis (New York, 1986).

20. Raise your glass and drink without shame / to the health of the youth who fought in the war / the Yemenites, the Algerians, the German Jews_/ the religious youth and the disco goers. Another, more elaborate example of this narrative can be seen in the 197I film Katz and Carasso, by the prolific B-movie director, Menahem Golan, which involves the competition between two insurance salesmen, the Ashkenazi Katz and the Sephardi Carasso (Sephardi and not Mizrahi because the Carasso family's use of Ladino, Jewish-Spanish). Both compete for the same lucrative client, which they pursue with the help of their children, who are groomed as heirs to their parents' business. Despite the hashed plot and predictable characterization, 
the film features some of the best type-acting in Israeli cinema in general and the Bourekas genre in particular, with Shmuel Rodensky and Yosef Shiloach in the title roles. The direction, too, is inspired for the genre, especially in the meticulous symmetry it maintains between the two sides. Much of the comedy derives from the parallel editing that goes back and forth between the two main characters and their families and constitutes an ironic commentary on their perceived differences. The two men may look, speak, act, and eat differently, but on the most basic, technical level, they are in fact identical. The symmetry between the two men is completed in the end by the marriage of Katz and Carasso's children. None of Katz' daughters and Carasso's sons seem interested in the rivalry between their fathers, professionally or ethnically. This is true even before they fall in love and marry. The marriage completes and seals the parity that the film maintains between the two men, who can no longer compete with one another after their children marry; they are now one big happy family. The Mizrahim and Ashkenazim in the film may be contrived and may have reflected little of Israeli society at the time, but it provided a powerful vision nevertheless.

2I. The film is much closer to George Ovadia's melodramas than to Bourekas, although it does retain this element of the genre.

22. Compare the iconic 1967 film Guess Who's Coming to Dinner? on interracial marriage in America. The very discussion the film raises about the validity of such marriage (few US films raised the issue) underscores the Israeli difference.

23. The issue has been studied extensively in the last decade or so. See for example Daniel Boyarin, Unheroic Conduct: The Rise of Heterosexuality and the Invention of the Jewish Man (Berkeley, CA, 1997) and Michael Gluzman, In the City of Slaughter: A Re-examination of Bialik's Poem on its Iooth Anniversary (Tel-Aviv, 2005) [Hebrew].

24. The power and penetration of this novel Jewish image can be seen in Otto Preminger's Hollywood 1960 box office hit, Exodus, in which Paul Newman plays Ari Ben-Kna’an, a new Hebrew farmer-fighter in Israel's war for independence.

25. The film is based on a 1954 play by Yigal Mossinsohn who originally set it in the first years after independence. The 1974 film version was contemporized to make Siman-Tov a soldier in the 1967 War. The original play reflected the fate of many Mizrahi soldiers in the War of Independence. Because they were relatively new in the country and lacked the social and political connections of many Ashkenazim, they were unable to play a similarly active role in the social and economic life of the new country after the war. See Yehudit Hendel, Rehov Hamadregot (Tel-Aviv, 1954) [Hebrew].

26. Yosef, "The Invention of Mizrahi Masculinity," IO2.

27. This is true of films about these tensions written and directed by Ashkenazim or featuring Ashkenazi actors who portrayed Mizrahim. It is not necessarily as ironic as some critics suggest. Iconic images are often created from the outside, by members of one group about another as expressions of fear, wishful thinking, or as projections. Two examples are the negative images of Jews in the European 
anti-Semitic imagination and the iconic images of cowboys in American classic Hollywood cinema. The first was created by non-Jews about Jews out of competition and fear while the second were the projections of wishful-thinking by Jewish filmmakers about a non-Jewish culture they desired to adopt and enter.

28. Gilya Gerda Schmidt, The Art and Artists of the Fifth Zionist Congress, IgoI (New York, 2003).

29. See the introduction to my study, Orientalism and the Hebrew Imagination.

30. James Diamond, Homeland or Holy Land? The Canaanite Critique of Israel (Bloomington, IN, i986).

3I. Amos Oz, "The Trapists' Monastery," (I962) in his, Where the Jackals Howl (Tel-Aviv, 1980) [Hebrew]. Itsche is a legendary IDF commando, an exaggerated version of the Palmachnik, who dreams of becoming a bus driver after his discharge.

32. The image of the broken, dejected, and humiliated Mizrahi father unable to provide for his family is common in memoirs and other works. See Sami Michael, Protection (Tel-Aviv, 1977) [Hebrew]; Eli Amir, Scapegoat (Tel-Aviv, 1993) [Hebrew].

33. An essentially identical imagery is set up in the more serious and ambitious film, Light Out of Nowhere (1973) filmed in black and white, written and directed by Nissim Dayan in a new realistic style. Light looks like a documentary version of Kazablan, even though it does not focus too much on Mizrahi-Ashkenazi tensions and lacks a central love story. Light does depict, however, a depressed Mizrahi neighborhood and community that offer very few choices to its members. The story centers on two brothers and their father. The older brother Baruch (Abie Zaltzberg) is the leader of a street gang. The younger brother Shaul (Nissim Levy) is on the verge of manhood and has to choose whether to defy the establishment and become a gangster like his brother or become a manual laborer like his father. Shaul chooses neither, leaving the question open. Both Kazablan and Light Out of Nowhere link the machismo of Mizrahi images to crime. This is no coincidence, since the exaggerated expressions of masculinity among criminals stem from some of the same frustrations, like the need to compensate for the lack of power in the "upperworld" with a big show of it in the underworld.

34. Sexual potency as a Mizrahi trait is common in cotemporary Hebrew literature. A. B. Yehoshua's novel The Lover (Tel-Aviv, 1977) recounts the sexual usurpation of the novel's Ashkenazi paterfamilias by the younger, Sephardi Arditi, who becomes the lover of the protagonist's wife. Amos Oz's Black Box (Tel-Aviv, 1987) sets the same dichotomy between the cold and barren Ashkenazi paterfamilias, Alexander Gideon, and his warm and sexual Mizrahi foil, Michel Sommo, who replaces him and marries Gideon's ex-wife, Ilana. Yehoshua Kenaz's novel, Infiltration endows one of the main characters in the novel, the Sephardi Avner, with marked sexual prowess.

35. Yosef, "The Invention of Mizrahi Masculinity," Io6.

36. Yahoo Carasso (Gadi Yagil) is initially portrayed as shy and diffident while 
Tikky Katz (Nitza Shaul), later his girlfriend, is more assertive and rebellious. This aberration is gradually corrected after Yahoo runs away from home to join his more "manly" brother.

37. The two lovers are given just enough attention to make their love story plausible. More time is devoted to the cultural, social, and economic differences between them.

38. Earlier studies by Nurit Gertz and Miri Talmon note this phenomenon as well. Both mention the changes in the perception and depiction of the native Sabra, which was increasingly associated in Bourekas and other films with a Mizrahi character. Gertz writes that these new Mizrahi heroes were often juxtaposed against effete, intellectual Ashkenazim (Motion Fiction, Israeli Fiction in Film, 30). "The more successful ethnic Bourekas films express the popular, unwritten norm, that privileges mischievous, anarchical and native-Israeli masculinity and by projecting it on the ethnic Mizrahi hero they move him from the margins of society into the bosom of the Israeli collectivity," Talmon in Miri Talmon, Lost Sabra Blues (Tel-Aviv, 200I) I46 [Hebrew].

39. The film includes elements from Bourekas films, like ethnic humor and a heavy reliance on music but it does not rely dramatically on ethnic tensions.

40. There is no overt indication, but the time of its release, obvious escapist qualities, and the film's soundtrack (almost exclusively made up of I950s American pop songs) makes this assessment plausible. See Dror Mish'ani, The Ethnic Unconscious: The Emergence of Mizrahiut in the Hebrew Literature of the Eighties (Tel-Aviv, 2006) [Hebrew].

4I. Momo's masculinity is not informed by these paradigms either. It may, however, be informed by Mizrahi masculine imagery. Although he is Ashkenazi, he is darker than his two friends. See Noam Yoran, "Pickled Lemon," Maaravon, I (winter, 2005-6) I7-26 [Hebrew].

42. Whether the Mizrahi vote for Likud improved their socio-economic status is debatable, however, it found a political, rather than just a cultural expression.

43. According to Rubik Rosenthal's Dictionary of Slang (Jerusalem, 2005) laflaf was coined in the I990s by Jojo Chalastra, (TV personality Zvika Hadar), just the last in a long series of names for the same kind of man, like yoram, gnicht, nachnach.

44. "The New Ars," Ha'aretz, September 6, 2002.

45. There were other, more common types of masculinity that were less polarized. I use these two extremes mainly for illustration. See note 38 above.

46. Asher's nonsensical character is one of a number of similar responses to these frustrations. Several other artists at the end of the I980s and early I990s used nonsense as one of their chief artistic modes of expression. These include Orly Castel-Bloom's short stories and novels, playwright and television writer Yosef Al-Dror, who inspired a nonsensical school that was very influential during those years and included the popular weekly Ha'ir and the hugely successful television skit show The Chamber Quintet. 
47. Gertz writes: "Although these films purported to express the rebellion of Sephardim against Israeli Ashkenazi society, which marginalized them, they actually forced the Sephardi hero to conform to its norms at the end." Motion Fiction, Israeli Fiction in Film, 3I. 